\title{
Synthesis and Biological Evaluation As Microtubule-Active Agents of Sev- eral Tetrahydrofuran and Spiroacetal Derivatives
}

\author{
M. Carda*, ${ }^{\text {,a }}$ J. Murga ${ }^{\mathrm{a}}$, J. Paños ${ }^{\mathrm{a}}$, C.A. Angulo-Pachón ${ }^{\mathrm{a}}$, J. García-Pla ${ }^{\mathrm{a}}$, S. Díaz-Oltra ${ }^{\mathrm{a}}$, \\ J.A. Marco*, ${ }^{*}$, C. Trigilic, M. Redondo-Horcajo ${ }^{\mathrm{c}}$, J.F. Díaz*,c and I. Barasoain*,c
}

${ }^{a}$ Depart. de Q. Inorgánica y Orgánica, Univ. Jaume I, E-12071 Castellón, Spain; ${ }^{b}$ Depart. de Q. Orgánica, Univ. de Valencia, E-46100 Burjassot, Valencia, Spain; ${ }^{C}$ Centro de Investigaciones Biológicas, Consejo Superior de Investigaciones Cientificas, 28040 Madrid, Spain

\begin{abstract}
The stereoselective preparation of several molecules containing structural fragments of the tetrahydrofuran and spiroacetal type is described. Their degree of cytotoxicity and their interactions with tubulin have been investigated. It has been confirmed that the tetrahydrofuran derivatives are cytotoxic but, in contrast to previous reports, it has been found that the cytoxicity is not due to interactions with the microtubule network. Furthermore, and also in contrast to a previous report on closely related compounds, the spiroacetal derivatives do show interactions with tubulin, even though the precise mechanism and the binding site still remain to be established.
\end{abstract}

Keywords: Tubulin, microtubules, cytoskeleton, microtubule-disrupting compounds, apoptosis, cytotoxicity, antitumoral drugs, anticancer therapy, bioactive structural fragments, tetrahydrofuran derivatives, spiroacetals.

\section{INTRODUCTION}

Microtubules are dynamic polymers which play a central role in a number of cellular processes, most particularly cell division, as they are key constituents of the mitotic spindle [1]. Their shape can be described as hollow tubes of about 25 $\mathrm{nm}$ external diameter constituted of a protein named tubulin. The functional form of this protein is a heterodimer formed in turn through non-covalent binding of two monomeric constituents. These are two structurally related polypeptides of about 450 amino acid residues which are called $\alpha$ - and $\beta$ tubulin [2]. For cell division to occur in a normal way, microtubules must be in a constant state of formation and disruption, a process named microtubule dynamics in which GTP hydrolysis into GDP plays a key role [3].

It is easy to understand that any molecule which exerts some type of action on microtubule dynamics will be able to influence the cell division process, not only of normal cells but also of tumoral ones. Since such an influence may be exerted by molecules that bind to any of the tubulin components, it is not surprising that tubulin-binding molecules (TBMs) constitute a very important class of anticancer agents [4]. TBMs are able to interfere with microtubule assembly and functions, either by causing disruption of the microtubules or else through their stabilization. In both cases, this results in mitotic arrest of eukaryotic cells and subsequent cell death, likely by an apoptosis-like process called mitotic catastrophe [5]. Most of the hitherto described active drugs are natural products or derivatives thereof [6].

*Address correspondence to this author at the Depart. de Q. Orgánica, Univ. de Valencia, E-46100 Burjassot, Valencia, Spain; Tel: +34 96 3544337; E-Mail: alberto.marco@uv.es
Major drugs can already be found on the market and many other promising compounds are in clinical trials $[4,6]$.

TBMs may be divided in two broad categories, those that bind to $\alpha$-tubulin and those that bind to $\beta$-tubulin. The latter group is presently by far the most numerous and contains products which cause either disruption or stabilization of microtubules. Among the drugs that belong to this group, the well-known colchicine [7] exerts its effects by causing disruption of microtubules. In contrast, another renowned representative of the same group, paclitaxel, was the firstdescribed tubulin-interacting drug with the ability to stabilize microtubules [8]. Despite the fact that they exert opposite effects on the mitotic spindle, both drugs are known to bind to $\beta$-tubulin, even though to different sites within that protein subunit. The mechanisms of action [9] of many of these TBMs and the molecular aspects [10] of their interactions with tubulin have been studied using a broad palette of methods [11].

The number of products reported to bind to $\alpha$-tubulin is very small, the naturally occurring 5,6-dihydro- $\alpha$-pyrone pironetin Fig. (1) being the first example [12], followed a short time later by the peptide-like hemiasterlin family [13]. Pironetin proved a potent inhibitor of tubulin assembly and was found to arrest cell cycle progression in the G2/M phase [14]. This feature has motivated a number of groups to undertake total syntheses of this natural compound [15]. Some synthetic and biological studies on modified variants of pironetin have previously been published [16].

The development of lipophilic tetrahydrofuran derivatives such as the two compounds named with the acronyms COBRA-0 or COBRA-1 Fig. (1) was the result of computerassisted studies based on previously published structural data 
of tubulin [17]. A potential drug binding cavity was identified on the surface of the $\alpha$-tubulin subunit that contained a remarkable abundance of hydrophobic aminoacid residues, mainly leucine and isoleucine. It was then postulated that this cavity could accommodate a long aliphatic chain with a length of up to twelve carbon atoms. Due to the additional S9-S10 loop present in $\alpha$-tubulin but not in $\beta$-tubulin $[2,3]$, this binding cavity would be present in the former and not in the latter subunit. With these ideas in mind, the synthetic anticancer compound COBRA-0 was designed to fit within the aforementioned hydrophobic cavity, a conclusion supported by docking studies. Similar studies led shortly afterwards to the design of COBRA-1, a variant of COBRA-0. Both compounds were reported to be cytotoxic and also to inhibit tubulin polymerization in the presence of GTP [18].

a)

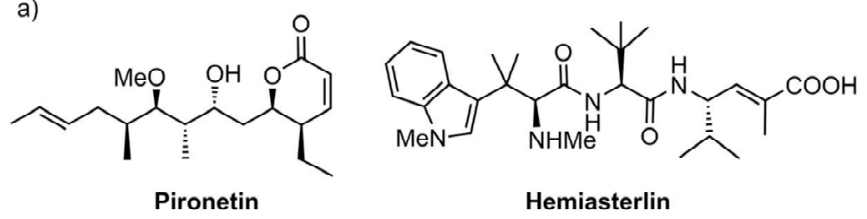

b)
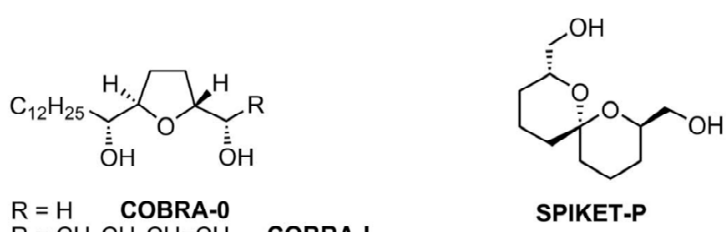

$\mathrm{R}=\mathrm{H} \quad$ COBRA-0
$\mathrm{R}=\mathrm{CH}_{2} \mathrm{CH}_{2} \mathrm{CH}=\mathrm{CH}_{2} \quad$ COBRA-I

c)

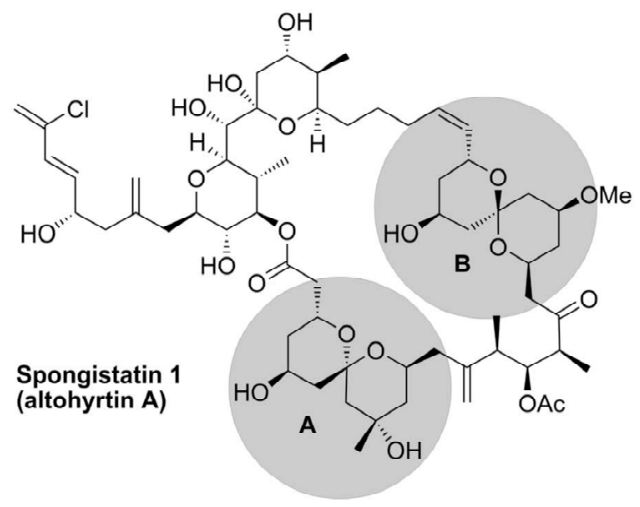

Fig. (1). (a) Structures of two natural products reported to selectively bind to $\alpha$-tubulin. (b) Structures of some synthetic products reported to selectively bind to $\alpha$-tubulin (COBRA type) and to $\beta$ tubulin (SPIKET-P). c) Structure of spongistatin 1 (altohyrtin A), with the two 6,6-spiroacetal fragments $\mathbf{A}$ and $\mathbf{B}$ highlighted.

A further type of nonnatural compounds designed to interact with tubulin were simple spiroacetal derivatives [17, 19] such as SPIKET-P Fig. (1). These compounds were designed taking the cytotoxic macrolides of the spongistatin class as a reference model. The molecules of these natural compounds, which are very strong inhibitors of the growth of many types of cancer cells [20], contain a plethora of functional groups, among them are two 6,6-spiroacetal fragments [21]. As a result of structural studies on tubulin, a region was identified in the $\beta$-tubulin subunit which could accommodate the large molecular volume of spongistatin 1 , the most active member of the spongistatin family Fig. (1) [22]. The proposed binding pocket contacts the longitudinal interdimer interface of the microtubule [17]. Computer-assisted studies of the interaction of spongistatin 1 with the putative binding pocket suggested that the two spiroacetal fragments $\mathrm{A} / \mathrm{B}$ of spongistatin 1 could form close contacts with certain protein residues in the pocket. This led the authors to wonder whether structurally simple molecules such as SPIKET-P containing the critical spiroacetal fragment might become a pharmacophoric surrogate for spongistatin 1 [19]. Indeed, the authors reported for SPIKET-P the ability to disrupt the mitotic spindle in human breast BT-20 cancer cells at a very low concentration $(10 \mathrm{nM})$ [23]. However, it is also worth noting that a later reinvestigation of all these findings by another group called them into question. This group found that neither SPIKET-P nor a closely related analog showed a measurable activity against several human cancer cell lines. Furthermore, they neither inhibited polymerization of tubulin nor caused polymer disassembly using several assays [24].

Recently, we have become interested in investigating the synthesis and biological properties of nonnatural TBMs with comparatively simple structures and the ability to selectively bind to $\alpha$-tubulin. We have disclosed the synthesis and the biological evaluation as tubulin-active agents of a library of simplified pironetin analogs. We have been able to confirm that these nonnatural analogs bind to $\alpha$-tubulin with the same mechanism as the parent compound, although with a reduced affinity [25]. The present paper reports further results of our group in the same line of research.

\section{RESEARCH PURPOSE}

The reasons of our interest in preparing compounds of the tetrahydrofuran and spiroacetal type arise from our ongoing research project to design pharmacologically active TBMs with hybrid structures. One part of such hybrid molecules should contain a fragment of the pironetin type, known to bind to $\alpha$-tubulin [12]. The other part was initially projected to be either a COBRA-type tetrahydrofuran fragment (reported to bind to $\alpha$-tubulin) or else a spiroacetal fragment (reported to bind to $\beta$-tubulin). The idea behind this purpose is to obtain compounds able to interact with two binding points in the tubulin polymeric chain. In view of the literature precedents, including the aforementioned unclear biological aspects, we decided to undertake the stereoselective preparation of several simple molecules of both structural types, as well as to investigate their biological profile. The present paper presents our recent results in this direction.

\section{CHEMICAL RESULTS}

We have synthesized tetrahydrofuran derivatives 1-5 and spiroacetals 6-9, as well as the enantiomers ent-6 to ent-9 Fig. (2). From the former, compound 1 corresponds to the previously described COBRA-1 [18b], which was prepared for the sake of comparison with the other analogs.

\section{Tetrahydrofuran Derivatives}

Tetrahydrofuran derivatives 1-5 were prepared from the known epoxide 10 [26] by means of copper-catalyzed epoxide ring opening [27] with Grignard reagents (Scheme 1). 
<smiles>C=CCC[C@@H](O)[C@@H]1CC[C@@H]([C@@H](O)CCCCCC)O1</smiles>

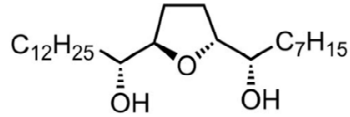
3<smiles>C=CC[C@@H]1C[C@@H](O)C[C@]2(CC(O)CCO2)C1</smiles>
6<smiles>C=CC[C@@H]1CC(O)C[C@]2(C[C@@H](O)CCO2)O1</smiles>

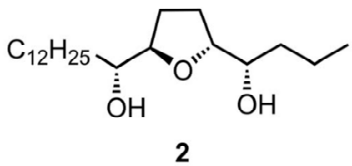

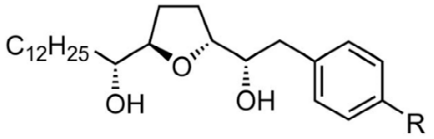
$\begin{array}{ll}4 \mathrm{R} & =\mathrm{H} \\ \mathbf{5} & \mathrm{R}=\mathrm{OM}\end{array}$<smiles>C=CC[C@@H]1C[C@@H](O)C[C@]2(C[C@@H](O)CCO2)C1</smiles><smiles>C=CCC1CC(O)CC2(C1)OCC[C@@H](O)O2</smiles>

Fig. (2). Tetrahydrofuran (1-5) and spiroacetal derivatives 6-9 prepared in the course of this investigation (the enantiomers ent-6 to ent-9 are not depicted).

$$
\begin{aligned}
& \underset{\mathrm{O} H}{\mathrm{C}_{12} \mathrm{H}_{25}} \underset{\substack{\mathrm{O} \\
10}}{\stackrel{\mathrm{RMgBr}, \mathrm{Cul} \text { (cat.) }}{(51-80 \%)}} \\
& \begin{array}{ll}
1 \mathrm{R}=\mathrm{CH}_{2}=\mathrm{CHCH}_{2} & 2 \mathrm{R}=\mathrm{Et} \\
3 \mathrm{R}=\mathrm{C}_{6} \mathrm{H}_{13} & 4 \mathrm{R}=\mathrm{Ph}
\end{array}
\end{aligned}
$$

Scheme 1. Synthesis of tetrahydrofuran derivatives 1-5.

\section{Spiroacetals}

Compounds 6-9 and their respective enantiomers were prepared as depicted in (Scheme 2) for spiroacetals 6 and $\mathbf{8}$. The known alcohol 11 [28] as first protected as its SEM [29] derivative 12 and then subjected to a Wacker oxidation [30] to yield ketone 13. Furthermore, alcohol 11 was first silylated and then subjected to selective desilylation to yield primary alcohol 15, Swern oxidation [31] of which provided aldehyde 16.

The aldol reaction of aldehyde $\mathbf{1 6}$ with the boron enolate [32] of ketone 13, generated with the aid of di- $n$-butylboron triflate, provided an inseparable mixture of aldol 17 and its epimer 18 at the hydroxyl-bearing carbon atom (diastereoisomeric ratio about 66:34) $[33,34]$. Treatment of the mixture of epimers with aqueous HF caused cleavage of the SEM and TBS groups, followed by spiroacetalization [22], to afford 6 and 8, which were separated. The remaining spiroacetals were obtained following the same methodology (for details of the experimental procedures and stereochemical assignments, see Supplementary Material).

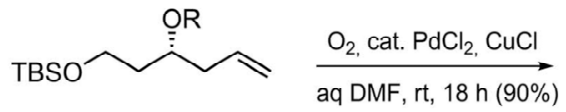

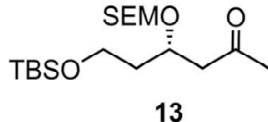

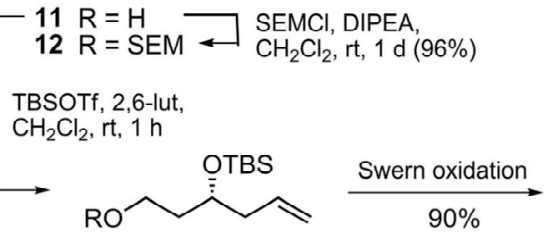

$14 \mathrm{R}=$ TBS $\longrightarrow$ HF-py, THF, rt,

$15 \mathrm{R}=\mathrm{H} \longleftarrow 4 \mathrm{~h}$ (96\% overall)

13

$13 \frac{\begin{array}{l}\text { 1: } \mathrm{Bu}_{2} \mathrm{BOTf}, \text { DIPEA, } \\ \mathrm{CH}_{2} \mathrm{Cl}_{2},-78^{\circ} \mathrm{C}\end{array}}{\begin{array}{c}\text { 2: } 16, \mathrm{CH}_{2} \mathrm{Cl}_{2},-78^{\circ} \mathrm{C}, 2 \mathrm{~h} \\ (61 \%, \text { d.r. } 66: 34)\end{array}}$
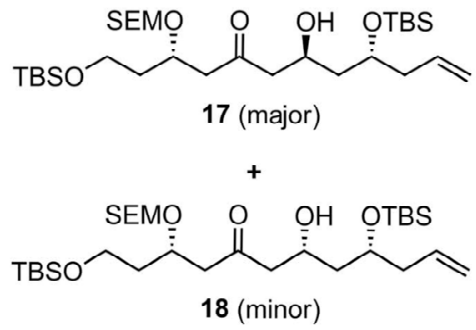

$17+18 \underset{\mathrm{rt}, 18 \mathrm{~h}}{\stackrel{\mathrm{aq} \mathrm{HF}, \mathrm{MeCN}}{\longrightarrow}}$

Scheme 2. Synthesis of spiroacetals 6 and 8. Acronyms: DIPEA, N,N-diisopropyl ethylamine ; SEM, 2-(trimethylsilyl)ethoxymethyl.

\section{BIOLOGICAL RESULTS}

\section{Cellular Effects of the Compounds}

\section{Tetrahydrofuran Derivatives 1-5}

In order to check the cytotoxicity of tetrahydrofuran derivatives $\mathbf{1 - 5}$, we determined the corresponding $\mathrm{IC}_{50}$ values on the A2780 and A2780AD human ovarian cancer cell lines (Table 1). Compounds 1-5 were found to be cytotoxic towards both the sensitive and the resistant cell lines, with $\mathrm{IC}_{50}$ values situated within the $18-58 \mu \mathrm{M}$ range.

Since previous studies with 1 suggested that compounds of this structural type have a depolymerizing (i.e. microtubule-disrupting) effect on microtubules, we studied the effect of ligands 1-5 on the microtubule cytoskeleton. We incubated A549 cells in the presence of these ligands for 24 hours. As shown in Fig. (3), $100 \mu \mathrm{M} 1$ (E,F), as well as both $100 \mu \mathrm{M} 3$ (see Supplementary Material) and $100 \mu \mathrm{M} 5$ (results not shown), do not show significant effects on cellular microtubules or DNA morphology. Compounds 2 and $\mathbf{4}$ at a $50 \mu \mathrm{M}$ concentration did not show any effect, either. The effect observed at a higher concentration $(200 \mu \mathrm{M})$ of compounds $5(C, D)$ and $1(G, H)$ is similar to that previously described for $\mathbf{1}$ and is probably due to a general cytotoxic effect that results in detachment of the cells from the plate: the microtubules are thus disorganized but not depolymerized. However, the nuclei in the cells have shrunk and are smaller than that of control cells as a consequence of the cytotoxicity 
Table 1. Effect of Tetrahydrofuran Derivatives 1-5 on the Growth of A2780 and A2780AD (MDR Overexpressing P-glycoprotein) Ovarian Carcinomas

\begin{tabular}{|c|c|c|c|}
\hline Ligand & $\mathbf{A 2 7 8 0}(\mu \mathrm{M})^{\mathrm{a}}$ & $\mathrm{A} 2780 \mathrm{AD}(\mu \mathrm{M})^{\mathrm{a}}$ & $\mathbf{R} / \mathbf{S}^{\mathbf{b}}$ \\
\hline Paclitaxel & $0.002 \pm 0.0003$ & $1.3 \pm 0.028$ & 650 \\
\hline 1 & $28.8 \pm 2.2$ & $58.3 \pm 11.5$ & 2 \\
\hline 2 & $28.6 \pm 1.45$ & $29.4 \pm 1.14$ & 1.02 \\
\hline 3 & $42.3 \pm 11$ & $52 \pm 6.5$ & 1.23 \\
\hline 4 & $18.5 \pm 0.067$ & $31.3 \pm 1.03$ & 1.7 \\
\hline 5 & $20 \pm 0.32$ & $31.7 \pm 0.208$ & 1.58 \\
\hline
\end{tabular}

${ }^{a}$ Values mean $\mathrm{IC}_{50}$ as the mean \pm standard error of three independent experiments.

${ }^{\mathrm{b}}$ Resistance index (the relative resistance of $\mathrm{A} 2780 \mathrm{AD}$ cell line, obtained dividing the $\mathrm{IC}_{50}$ of the resistant cell line by that of the parental A2780 cell line).
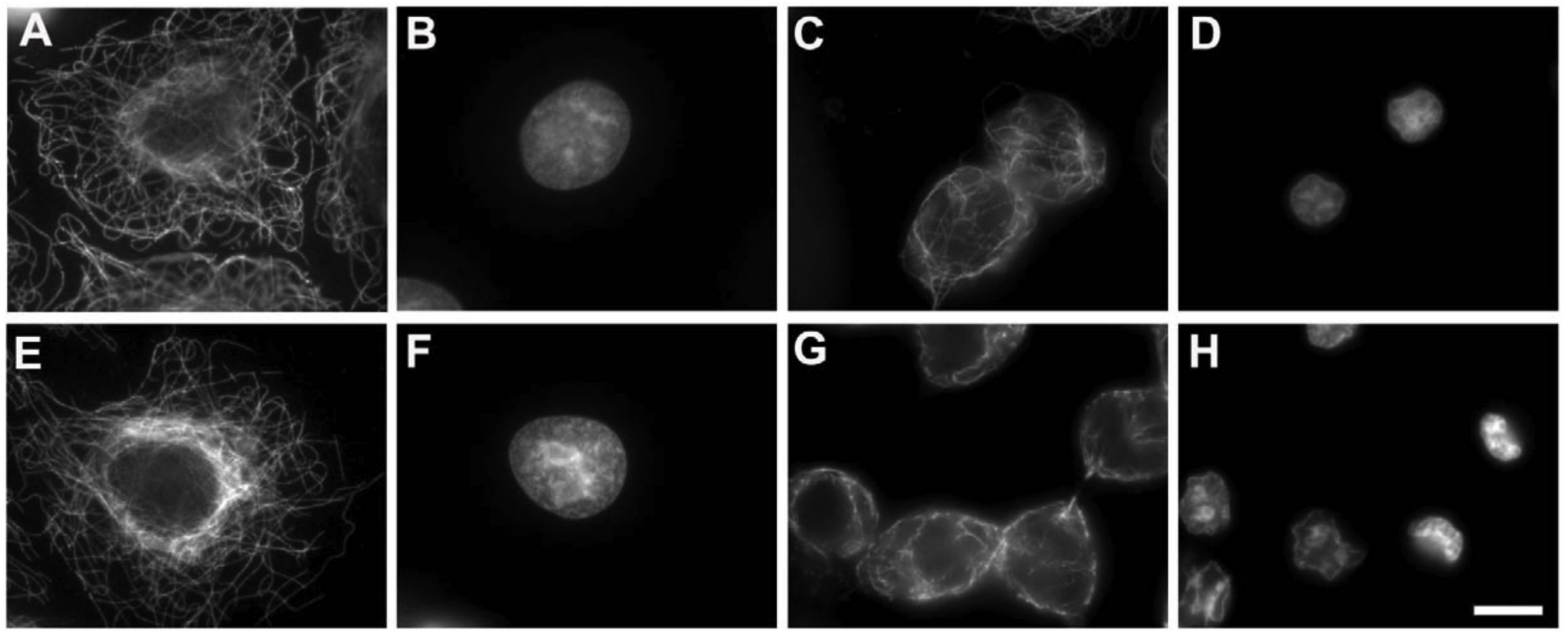

Fig. (3). Effect of the treatment with tetrahydrofuran derivatives $\mathbf{1}$ and $\mathbf{5}$ on the cytoplasmic microtubule network (A, C, E, G) and DNA (B, D, F, H) of A549 lung carcinoma cells. The cells were incubated with DMSO (A,B), $200 \mu \mathrm{M} \mathbf{5}(\mathbf{C}, \mathbf{D}), 100 \mu \mathrm{M} 1$ (E,F), and $200 \mu \mathrm{M} 1$ (G,H). For the other tetrahydrofuran derivatives, see Supplementary Material. Microtubules were immunostained with $\alpha$-tubulin monoclonal antibodies; DNA was stained with Hoechst 33342. Scale bar $=10 \mu \mathrm{m}$.

of these compounds. This effect was also observed with 100 $\mu \mathrm{M} 2$ and 4 (see Supplementary Material).

We also studied the effect of these compounds on the cell cycle of A549 cells (see Table 5). Even concentrations of $100 \mu \mathrm{M}$ or higher of $\mathbf{1 - 5}$ did not alter the cell distribution in a significant way as compared with the control cells (Table $\mathbf{5}$ only depicts results obtained with $\mathbf{1}$ and $\mathbf{3}$ but similar results were observed for $\mathbf{2 , 4}$ and $\mathbf{5}$ ).

These observations were confirmed by the absence of inhibition of purified tubulin microtubule assembly. The critical concentration of tubulin required for assembly was determined in GAB in the presence of a large excess $(100 \mu \mathrm{M})$ of compounds 1-5 (Table 2). As shown in the Table, the concentration of tubulin required to produce assembly (critical concentration [35]) oscillate between 3.0 and $3.5 \mu \mathrm{M}$ in the presence of these compounds, similarly as in their absence $(3.3 \mu \mathrm{M})$. The observed in vitro effect correlates well with the immunofluorescence results shown in Fig. (3).
Table 2. Critical Concentration Values of Tubulin for Ligand-induced Microtubule Assembly Induced by Tetrahydrofuran Derivatives 1-5 (Ligand Concentrations are $25 \mu \mathrm{M}$ for Docetaxel and $100 \mu \mathrm{M}$ for the Ligands)

\begin{tabular}{|c|c|}
\hline Ligand & $\operatorname{Cr}(\boldsymbol{\mu} \mathbf{M})^{\mathbf{a}}$ \\
\hline \hline Control & $3.3 \pm 0.5$ \\
\hline Docetaxel & $1.1 \pm 0.3$ \\
\hline $\mathbf{1}$ & $3.4 \pm 0.2$ \\
\hline $\mathbf{2}$ & $3.5 \pm 0.1$ \\
\hline $\mathbf{3}$ & $3.0 \pm 0.3$ \\
\hline $\mathbf{4}$ & $3.2 \pm 0.4$ \\
\hline $\mathbf{5}$ & $3.3 \pm 0.2$ \\
\hline
\end{tabular}

${ }^{a} \mathrm{Cr}$ values are the mean \pm standard error of three independent experiments. 
Table 3. Effect of Spiroketals 6-9 and ent-6/ent-9 on the Growth of A2780 and A2780AD (MDR Overexpressing P-glycoprotein) Ovarian Carcinomas

\begin{tabular}{|c|c|c|c|}
\hline Ligand & $A 2780(\mu M)^{a}$ & $\operatorname{A2780AD}(\mu M)^{a}$ & $\mathbf{R} / \mathbf{S}^{\mathbf{b}}$ \\
\hline Taxol & $0.002 \pm 0.0003$ & $1.3 \pm 0.028$ & 650 \\
\hline 6 & $>300^{c}$ & $>300^{c}$ & - \\
\hline ent-6 & $>300^{\mathrm{c}}$ & $>300^{\mathrm{c}}$ & - \\
\hline 7 & $42 \pm 2.8$ & $\geq 100$ & - \\
\hline ent-7 & $95 \pm 3.5$ & $\geq 100$ & - \\
\hline 8 & $21.15 \pm 0.9$ & $84.7 \pm 0.2$ & 4 \\
\hline ent-8 & $>100^{\mathrm{c}}$ & $>100^{\mathrm{c}}$ & - \\
\hline 9 & $>300^{\mathrm{c}}$ & $>300^{c}$ & - \\
\hline ent-9 & $40.95 \pm 0.7$ & $44 \pm 4.2$ & 1.07 \\
\hline
\end{tabular}

${ }^{\mathrm{a}}$ Values mean $\mathrm{IC}_{50}$ as the mean \pm standard error of three independent experiments.

${ }^{\mathrm{b}}$ Resistance index (the relative resistance of A2780AD cell line, obtained dividing the $\mathrm{IC}_{50}$ of the resistant cell line by that of the parental A2780 cell line). ${ }^{\mathrm{c}}$ Not determined.
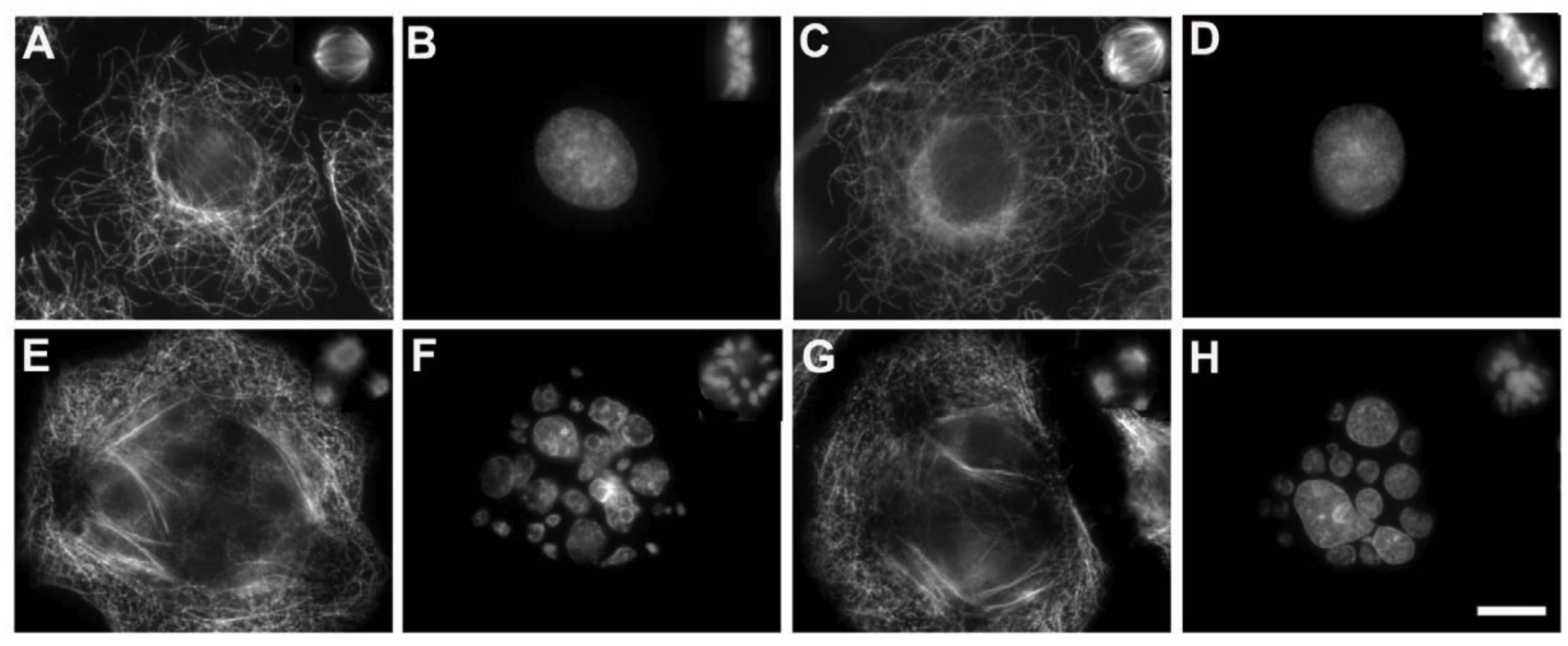

Fig. (4). Effect of the treatment with spiroacetals on the cytoplasmic microtubule network (A, C, E, G) and on DNA (B, D, F, H) of A549 lung carcinoma cells. The cells were incubated with DMSO (A,B), $300 \mu \mathrm{M} 6(\mathbf{C}, \mathbf{D}), 100 \mu \mathrm{M} 8$ (E,F) and $100 \mu \mathrm{M} 7$ (G,H). For the other spiroacetals, see Supplementary Material. Microtubules were immunostained with $\alpha$-tubulin monoclonal antibodies; DNA was stained with Hoechst 33342. Insets are mitotic spindles from the same preparation. Scale bar $=10 \mu \mathrm{m}$.

\section{Spiroacetals 6-9 and their Enantiomers}

As with compounds $\mathbf{1 - 5}$, we have determined the $\mathrm{IC}_{50}$ values for spiroacetals 6-9 and their enantiomers ent-6/ent-9 on the A2780 and A2780AD human ovarian cancer cell lines (Table 3). According to the results shown in the table, compounds 7, ent-7, 8 and ent-9 were found to be cytotoxic for the $\mathrm{A} 2780$ cancer cell line $\left(\mathrm{IC}_{50}<100 \mu \mathrm{M}\right)$, with 8 and ent-9 being also cytotoxic for the A2780AD cell line. The remaining spiroacetals were not cytotoxic at the concentrations tested.

When we studied the effect of the spiroacetals on the microtubule cytoskeleton of A549 cells, we found that concen- trations of compounds ent-6, ent-7, ent-8, 9 and ent-9 as high as $100-300 \mu \mathrm{M}$ have no effect on either the microtubule network or the DNA of these cells (see Fig. 2 in the Supplementary Material). Fig. (4) shows the results observed with ligands 6-8. Interestingly, it has been found that $100 \mu \mathrm{M} 8$ $(\mathrm{E}, \mathrm{F})$ and $100 \mu \mathrm{M} 7(\mathrm{G}, \mathrm{H})$ disorganize the microtubule network and induce cytoplasmic microtubule bundles, mitotic asters and micronucleated cells, all in the same way as microtubule-stabilizing agents do.

We studied as well the effect of these spiroacetals on the cell cycle of A549 cells. As a matter of fact, compounds 6, ent-6, ent-7, ent-8, 9 and ent-9 at concentrations up to 100 $\mu \mathrm{M}$ did not alter the cell cycle of these cells, the cell distri- 
bution being similar to that of control cells (results not shown). However, ligands $\mathbf{7}$ and $\mathbf{8}$ caused a substantial accumulation of cells in the $\mathrm{G} 2 / \mathrm{M}$ phase of the cell cycle ( $>$ $40 \%$ as compared with ca. $26 \%$ for the control), as well as the appearance of a sub G1 peak of presumably apoptotic cells (Table 5). In any case, ligands 6-9 and their enantiomers show a measurable depolymerizing effect on the in vitro assembly of microtubules. The critical tubulin concentration [35] required for assembly was determined in GAB in the presence of a large excess $(100 \mu \mathrm{M})$ of the compounds. As shown in (Table 4), the concentration of tubulin required to produce assembly increases substantially in the presence of compounds 7, 8 and ent $\mathbf{8}$, whereas $\mathbf{6}$, ent $-\mathbf{6}$, ent-7, 9 and ent-9 cause only a moderate increase in the critical concentration observed. Ligands 7, ent-8 and particularly $\mathbf{8}$ have a marked microtubule depolymerizing effect, with an increase of about $60-130 \%$ in the critical concentration being required for assembly.

Table 4. Critical Concentration Values of Tubulin for Ligand-induced Microtubule Assembly Induced by Spiroketals 6-9 and ent-6/ent-9 (Ligand Concentrations are $25 \mu M$ for Docetaxel and $100 \mu M$ for the Ligands)

\begin{tabular}{|c|c|}
\hline Ligand & $\mathbf{C r}(\boldsymbol{M})^{\mathbf{a}}$ \\
\hline \hline Control & $3.3 \pm 0.39$ \\
\hline Docetaxel & $1.1 \pm 0.2$ \\
\hline $\mathbf{6}$ & $3.5 \pm 0.6$ \\
\hline ent-6 & $4.1 \pm 0.6$ \\
\hline $\mathbf{7}$ & $5.4 \pm 1.0$ \\
\hline ent-7 & $4.3 \pm 0.3$ \\
\hline $\mathbf{8}$ & $7.7 \pm 0.1$ \\
\hline ent-8 & $6.3 \pm 0.8$ \\
\hline $\mathbf{9}$ & $3.8 \pm 0.8$ \\
\hline ent-9 & $4.0 \pm 0.7$ \\
\hline
\end{tabular}

${ }^{a} \mathrm{Cr}$ values are the mean \pm standard error of three independent experiments.

\section{DISCUSSION}

The results obtained indicate that the previously reported cytotoxic effects of COBRA-0 [17] and COBRA-1 (= compound 1) are confirmed in the case of $\mathbf{1}$. However, and in contrast with the conclusions of the previous report, these effects are not due to interactions with the microtubule network. First of all, no accumulation of cells in the G2/M phase, typical of compounds which block chromatide segregation by affecting microtubule dynamics of the cell cycle, is observed here. Secondly, they produce no visible effect in the microtubule network. Indeed, the micrographs shown in Fig. (3) are very similar to those previously published [18] and indicate that, as commented above, the cellular effect observed is due to a general cytotoxic effect which results in detachment of the cells from the plate, i.e., the microtubules are disorganized but not depolymerized. These findings have led us to discard these compounds for our projected preparation of hybrids.

The eight spiroacetals prepared by us (6-9 and their respective enantiomers) do not show the same substituent pattern as SPIKET-P but do share the same spiroacetal system and the presence of a carbon in the immediate vicinity of one of the spiroacetal oxygen atoms $(\mathrm{O}-1$, see numbering in Fig. 5). Furthermore, SPIKET-P shows the same configuration at the key atoms C-2 (which bears a carbon substituent) and C6 (anomeric carbon) as spiroacetals 7, 9, ent-6 y ent-8 Fig. (5). This suggests that all these spirocyclic compounds also share the same conformational shape [36].
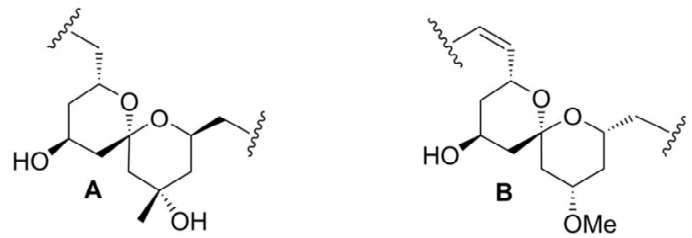

Structures of the spiroketal fragments of spongistatin 1 (altohyrtin A)
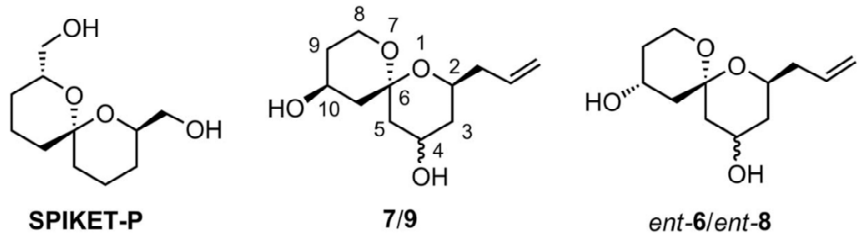

Fig. (5). The two spiroacetal fragments $\mathbf{A}$ and $\mathbf{B}$ of spongistatin 1 are compared with SPIKET-P and with spiroacetal pairs $\mathbf{7 / 9}$ and ent-6/ent-8 (fragment $\mathbf{B}$ has been redrawn).

It is also worth noting that the spiroacetal fragment $\mathbf{A}$ of spongistatin 1 also shows the same configurations at the two aforementioned stereocenters as the spiroacetals 7, 9, ent-6 y ent-8. This suggests that these spiroacetal derivarives may constitute a structurally close analog of SPIKET and a good model of fragment A of spongistatin 1 [37]. As regards spiroacetal fragment $\mathbf{B}$, it also shares stereochemical coincidences with spiroacetals 7,9 , ent-6 and ent-8 but only at C-6 and $\mathrm{C}-10$. However, the configuration is the opposite at $\mathrm{C}-2$ (that bearing a carbon substituent), C-4 or both. These spiroacetals may thus not constitute a good analog of fragment $\mathrm{B}$ of spongistatin 1 (for comparison of ${ }^{1} \mathrm{H}$ NMR data, see Supplementary Material).

In the case of the spiroacetal derivatives, compounds 7 and $\mathbf{8}$ show a clear effect in the cytoskeletal network Fig. (4). This supports the starting hypothesis that a core spiroacetal fragment of the spongistatin type is able to retain a significant fraction of the cytotoxicity of the parent compound through tubulin interaction. In vitro assembly studies show that the compounds are able to bind to purified tubulin and to inhibit its assembly, although with different degrees of potency. As expected from its higher cytotoxicity, compound $\mathbf{8}$ is the best inhibitor of tubulin polymerization, while 7 and ent $\mathbf{8}$ are still reasonably powerful.

The inmunofluorescence studies of cells indicate that the interaction of spiroacetals $\mathbf{7}$ and $\mathbf{8}$ with tubulin is reflected into the morphology of the cytoskeleton. Surprisingly, the main cellular effect observed is not the depolymerization of 
Table 5. Cell Cycle Distribution of A549 Cells Treated with Compounds 1, 3, 7 and 8 At Various Concentrations ${ }^{\mathrm{a}}$

\begin{tabular}{|c|c|c|c|c|}
\hline Ligand $(\mu \mathrm{M})$ & SubG1 & G0/G1 & $\mathbf{S}^{\mathbf{b}}$ & G2/M \\
\hline Control & - & $61.6 \pm 4$ & $12.5 \pm 4$ & $26.2 \pm 0$ \\
\hline $\mathbf{1}(25 \mu \mathrm{M})$ & - & $61 \pm 0.1$ & $8.4 \pm 2$ & $30.5 \pm 3$ \\
\hline $\mathbf{1}(50 \mu \mathrm{M})$ & - & $63 \pm 3$ & $8 \pm 4$ & $29 \pm 1$ \\
\hline $\mathbf{1}(100 \mu \mathrm{M})$ & - & $63 \pm 4$ & $12 \pm 3$ & $25 \pm 1$ \\
\hline $\mathbf{1}(200 \mu \mathrm{M})$ & - & $69 \pm 0.6$ & $13.8 \pm 1$ & $18 \pm 1$ \\
\hline $\mathbf{1}(300 \mu \mathrm{M})$ & $8.7 \pm 0$ & $51.5 \pm 0.5$ & $20 \pm 2$ & $18 \pm 1$ \\
\hline $3(25 \mu \mathrm{M})$ & - & $60 \pm 5$ & $6.4 \pm 4$ & $33 \pm 0.1$ \\
\hline $3(50 \mu \mathrm{M})$ & - & $67 \pm 0.5$ & $5.6 \pm 1$ & $26.6 \pm 1$ \\
\hline $3(100 \mu \mathrm{M})$ & - & $66 \pm 2$ & $10 \pm 1$ & $23 \pm 2$ \\
\hline $7(50 \mu \mathrm{M})$ & $8.3 \pm 0$ & $43 \pm 2.6$ & $8.5 \pm 3$ & $40.2 \pm 2$ \\
\hline $7(100 \mu \mathrm{M})$ & $22 \pm 1$ & $22.3 \pm 1$ & $8.5 \pm 1$ & $47.6 \pm 1$ \\
\hline $7(200 \mu \mathrm{M})$ & $22 \pm 0$ & $20 \pm 1$ & $8.4 \pm 0$ & $49 \pm 0.1$ \\
\hline $8(50 \mu \mathrm{M})$ & $20.8 \pm 2$ & $15 \pm 2$ & $18 \pm 2$ & $46 \pm 1$ \\
\hline $8(100 \mu \mathrm{M})$ & $18 \pm 1$ & $11.5 \pm 0$ & $13 \pm 0.5$ & $58 \pm 1$ \\
\hline $8(200 \mu \mathrm{M})$ & $17 \pm 2$ & $13 \pm 1.4$ & $10 \pm 0$ & $59 \pm 2$ \\
\hline
\end{tabular}

${ }^{a}$ Cells were incubated for 20 hours with several dilutions of each ligand. Numbers in the table are percentages (\%) of cells in each phase of the cell cycle (mean values \pm standard deviations of the results obtained in three experiments). The sub G1 peaks are presumably apoptotic cells.

the cytoskeleton but a bundling effect: the microtubular network appears disorganized and the microtubules are forming bundles. This is a typical effect of microtubule-stabilizing agents and suggests that, either the compounds are modified inside the cell and/or, at the intracellular concentrations and perhaps in the presence of other cellular proteins, the interactions of the two compounds with tubulin produce additional effects not observed in experiments in vitro.

In summary, we have shown that, in contrast to SPIKETP [24], several similar spiroacetals display cytotoxicity, show interactions with tubulin and have a measurable effect on the assembly of microtubules. However, the precise mechanism of action and the possible binding sites of these spiroacetals still remain to be established.

\section{MATERIALS AND METHODS}

\section{Chemistry. General Procedures}

The general reaction conditions and the physical and spectral data of all synthetic intermediates and final compounds are described in detail as Supplementary Material. The samples of all compounds used for the biological studies were purified to $>95 \%$ by means of preparative HPLC.

\section{Cell Culture}

Human A549 non small lung carcinoma cells were cultured in RPMI 1640 supplemented with 10\% FCS, glutamine, and antibiotics as previously described [38]. Human ovarian carcinomas A2780 and A2780AD (MDR overex- pressing P-glycoprotein) were cultured as above with the addition of 0.25 units $/ \mathrm{mL}$ of bovine insulin.

\section{Cytotoxicity Assays, Indirect Immunofluorescence and Cell Cycle}

Cytotoxic evaluation was performed with A2780 and A2780AD cells with the MTT assay modified as previously described [39]. Indirect immunofluorescence was performed in A549 cells that had been cultured overnight in $12 \mathrm{~mm}$ round coverslips and incubated a further 24 hours in the absence (drug vehicle DMSO) or in the presence of different ligand concentrations. Attached cells were permeabilized with Triton X100 and fixed with 3.7\% formaldehyde. Microtubules were specifically stained with DM1A $\alpha$-tubulin monoclonal antibodies and DNA with Hoechst 33342 as previously described [40]. The preparations were examined using a Zeiss axioplan epifluorescence microscope and the images were recorded in a Hamamatsu 4742-95 cooled CCD camera.

\section{Tubulin Assembly Inhibition Assay}

The effect of the compounds in the assembly of purified tubulin was determined by incubating $20 \mu \mathrm{M}$ purified tubulin at $37^{\circ} \mathrm{C}$ for 30 minutes in $\mathrm{GAB}$ (glycerol assembling buffer, $3.4 \mathrm{M}$ glycerol, $10 \mathrm{mM}$ sodium phospate, $1 \mathrm{mM}$ EGTA, 1 $\mathrm{mM} \mathrm{GTP}, 6 \mathrm{mM} \mathrm{MgCl}_{2}$ at $\mathrm{pH}$ 6.5) in the presence of $25 \mu \mathrm{M}$ docetaxel, $100 \mu \mathrm{M}$ of one of the analogs PTA-PF or JPP or 2 $\mu \mathrm{L}$ DMSO (vehicle). The samples were processed and the 
critical concentration for tubulin assembly [35] in the presence of the ligands calculated as described [41].

\section{CONFLICT OF INTEREST}

The author(s) confirm that this article content has no conflicts of interest.

\section{ACKNOWLEDGEMENTS}

Financial support has been granted by the Spanish Ministry of Education and Science (CTQ2008-02800), by the Consellería d'Empresa, Universitat i Ciencia de la Generalitat Valenciana (ACOMP09/113) and by the BANCAJA-UJI Foundation (P1-1B2002-06 and P1-1B-2008-14). The biological work has been supported in part by grants from the Spanish Ministry of Education and Science (BIO200761336) and from the Comunidad de Madrid (grants S2010/ BMD-2457 and BIPEDD2-CM) (both to J.F.D.). We further thank the Matadero Municipal Vicente de Lucas in Segovia for providing the calf brains which were the source of tubulin.

\section{SUPPLEMENTARY MATERIALS}

Supplementary material is available on the publisher's web site along with the published article.

\section{REFERENCES}

[1] Fojo, T., Ed. The Role of Microtubules in Cell Biology, Neurobiology and Oncology; Humana Press: Totowa, New Jersey, 2008.

[2] (a) Amos, L. A. Microtubule structure and its stabilization. Org. Biomol. Chem., 2004, 2, 2153-2160. (b) Wade, R. H. On and around microtubules. Mol. Biotechnol., 2009, 43, 177-191.

[3] (a) Nogales, E.; Wang, H.-W. Structural intermediates in microtubule assembly and disassembly: how and why?. Curr. Opin. Cell Biol., 2006, 18, 179-184. (b) Nogales, E.; Wang, H.-W. Structural mechanisms underlying nucleotide-dependent self-assembly of tubulin and its relatives. Curr. Opin. Struct. Biol., 2006, 16, 221-229.

(a) Beckers, T.; Mahboobi, S. Natural, semisynthetic and synthetic microtubule inhibitors for cancer therapy. Drugs Fut., 2003, 28, 767-785. (b) Hadfield, J. A.; Ducki, S.; Hirst, N.; McGown, A. T. Tubulin and microtubules as targets for anticancer drugs. Progr. Cell Cycle Res., 2003, 5, 309-325. (c) Jordan, M. A.; Wilson, L. Microtubules as a target for anticancer drugs. Nat. Rev. Cancer, 2004, 4, 253-265. (d) Chen, S.-H.; Hong, J. Novel tubulininteracting agents: a tale of Taxus brevifolia and Catharanthus roseus-based drug discovery. Drugs Fut., 2006, 31, 123-150. (e) Pasquier, E.; Kavallaris, M. Microtubules: a dynamic target in cancer therapy. IUBMB Life, 2008, 60, 165-170. (f) Singh, P.; Rathinasamy, K.; Mohan, R.; Panda, D. Microtubule assembly dynamics: an attractive target for anticancer drugs. IUBMB Life, 2008, 60, 368-375. (g) Morris, P. G.; Fornier, M. N. Microtubule active agents: beyond the taxane frontier. Clin. Cancer Res., 2008, 14, 7167-7172. (h) Perez, E. A. Microtubule inhibitors: Differentiating tubulin-inhibiting agents based on mechanisms of action, clinical activity, and resistance. Mol. Cancer Ther., 2009, 8, 20862095. (i) Chen, S. M.; Meng, L.-H.; Ding, J. New microtubuleinhibiting anticancer agents. Expert Opin. Invest. Drugs, 2010, 19, 329-343. (j) Calligaris, D.; Verdier-Pinard, P.; Devred, F.; Villard, C.; Braguer, D.; Lafitte, D. Microtubule targeting agents: from biophysics to proteomics. Cell. Mol. Life Sci., 2010, 67, 1089-1104. (k) Goyal, S. S.; Patel, R. M.; Sukhramani, P. S.; Kamothi, K. A. Microtubules: a novel target for cancer therapy. Int. J. Pharm. Sci. Res., 2010, 1, 1-21.

[5] (a) For a review, see: Portt, L.; Norman, G.; Clapp, C.; Greenwood, M.; Greenwood, M. T. Anti-apoptosis and cell survival: A review. Biochim. Biophys. Acta, 2011, 1813, 238-259. (b) See also: Llovera, L.; Mansilla, S.; Portugal, J. Apoptotic-like death occurs through a caspase-independent route in colon carcinoma cells undergoing mitotic catastrophe. Cancer Lett. 2012, 326, 114-121. (a) Altmann, K.-H.; Gertsch, J. Anticancer drugs from Nature-natural products as a unique source of new microtubulestabilizing agents. Nat. Prod. Rep., 2007, 24, 327-357. (b) Kingston, D. G. I. A natural love of natural products. J. Org. Chem., 2008, 73, 3975-3984. (c) Kingston, D. G. I. Tubulin-interactive natural products as anticancer agents. J. Nat. Prod., 2009, 72, 507515.

[7] Chen, J.; Liu, T.; Dong, X.; Hu, Y. Recent development and SAR analysis of colchicine binding site inhibitors. Mini-Rev. Med. Chem., 2009, 9, 1174-1190.

[8] Fu, Y.; Li, S.; Zu, Y.; Yang, G.; Yang, Z.; Luo, M.; Jiang, S.; Wink, M.; Efferth, T. Medicinal chemistry of paclitaxel and its analogs. Curr. Med. Chem., 2009, 16, 3966-3985.

[9] (a) Jordan, M. A. Mechanism of action of antitumor drugs that interact with microtubules and tubulin. Curr. Med. Chem.-Anticancer Drugs, 2002, 2, 1-17. (b) Abal, M.; Andreu, J. M.; Barasoain, I. Taxanes: microtubule and centrosome targets, and cell cycle dependent mechanisms of action. Curr. Cancer Drug Targets, 2003, 3, 193-203.

[10] (a) Correia, J. J.; Lobert, S. Physiochemical aspects of tubulininteracting antimitotic drugs. Curr. Pharm. Des., 2001, 7, 12131228. (b) Jiménez-Barbero, J.; Amat-Guerri, F.; Snyder, J. P. The solid state, solution and tubulin-bound conformations of agents that promote microtubule stabilization. Curr. Med. Chem.-Anticancer Drugs, 2002, 2, 91-122. (c) Díaz, J. F.; Andreu, J. M.; JiménezBarbero, J. The interaction of microtubule with stabilizers characterized at biochemical and structural levels. Top. Curr. Chem., 2009, 286, 121-149. (d) Gigant, B.; Cormier, A.; Dorléans, A.; Ravelli, R. B. G.; Knossow, M. Microtubule-destabilizing agents: structural and mechanistic insights from the interaction of colchicine and vinblastine with tubulin. Top. Curr. Chem., 2009, 286, 259-278. (e) Daly, E. M.; Taylor, R. E. Entropy and enthalpy in the activity of tubulin-based antimitotic agents. Curr. Chem. Biol., 2009, 3, 367-379.

[11] (a) Sánchez-Pedregal, V. M.; Griesinger, C. The tubulin binding mode of MT stabilizing and destabilizing agents studied by NMR. Top. Curr. Chem., 2009, 286, 151-208. (b) Nettles, J. H.; Downing, $\mathrm{K}$. H. The tubulin binding mode of microtubule stabilizing agents studied by electron crystallography. Top. Curr. Chem., 2009, 286, 209-257. (c) Botta, M.; Forli, S.; Magnani, M.; Manetti, F. Molecular modeling approaches to study the binding mode on tubulin of microtubule destabilizing and stabilizing agents. Top. Curr. Chem., 2009, 286,279-328.

[12] Sarabia, F.; García-Castro, M.; Sánchez-Ruiz, A. Chemistry and biology of novel microtubule-destabilizing agents that bind $\alpha$ tubulin. Curr. Bioact. Comp., 2006, 2, 269-299.

[13] Anderson, H. J.; Coleman, J. E.; Andersen, R. J.; Roberge, M. Cytotoxic peptides hemiasterlin, hemiasterlin A and hemiasterlin B induce mitotic arrest and abnormal spindle formation. Cancer Chemother. Pharmacol., 1997, 39, 223-226.

[14] Kondoh, M.; Usui, T.; Kobayashi, S.; Tsuchiya, K; Nishikawa, K.; Nishikiori, T.; Mayumi, T.; Osada, H. Cell cycle arrest and antitumor activity of pironetin and its derivatives. Cancer Lett., 1998, 126, 29-32. Kondoh, M.; Usui, T.; Nishikiori, T.; Mayumi, T.; Osada, H. Apoptosis induction via microtubule disassembly by an antitumour compound, pironetin. Biochem. J., 1999, 340, 411-416. (c) Watanabe, H.; Watanabe, H.; Usui, T.; Kondoh, M.; Osada, H.; Kitahara, T. Synthesis of pironetin and related analogs: studies on structure-activity relationships as tubulin assembly inhibitors. $J$. Antibiot., 2000, 53, 540-545. (d) Usui, T.; Watanabe, H.; Nakayama, H.; Tada, Y.; Kanoh, N.; Kondoh, M.; Asao, T.; Takio, K.; Watanabe, H.; Nishikawa, K.; Kitahara, T.; Osada, H. The anticancer natural product pironetin selectively targets Lys 352 of $\alpha$ tubulin. Chem. \& Biol., 2004, 11, 799-806.

[15] (a) Yasui, K.; Tamura, Y.; Nakatani, K.; Kawada, K.; Ohtani, M. Total Synthesis of (-)-PA-48153C, a novel immunosuppressive 2pyranone derivative. J. Org. Chem., 1995, 60, 7567-7574. (b) Gurjar, M. K.; Henri, J. T. Jr.; Bose, D. S.; Rao, A. V. R. Total synthesis of a potent immunosuppressant pironetin. Tetrahedron Lett., 1996, 37, 6615-6618. (c) Chida, N.; Yoshinaga, M.; Tobe, T.; Ogawa, S. Total synthesis of (-)-PA-48153C (pironetin) utilising 1- 
quebrachitol as a chiral building block. Chem. Comm., 1997, 10431044. (d) Watanabe, H.; Watanabe, H.; Bando, M.; Kido, M.; Kitahara, T. An efficient synthesis of pironetins employing a useful chiral building block, $(1 S, 5 S, 6 R)$-5-hydroxybicyclo[4.1.0]heptan-2one. Tetrahedron, 1999, 55, 9755-9776. (e) Keck, G. E.; Knutson, C. E.; Wiles, S. A. Total synthesis of the immunosupressant (-)pironetin (PA48153C). Org. Lett., 2001, 3, 707-710. (f) Dias, L. C.; de Oliveira, L. G.; de Sousa, M. A. Total synthesis of (-)-pironetin. Org. Lett., 2003, 5, 265-268. (g) Shen, X.; Wasmuth, A. S.; Zhao, J.; Zhu, C.; Nelson, S. G. Catalytic asymmetric assembly of stereodefined propionate units: an enantioselective total synthesis of (-)-pironetin. J. Am. Chem. Soc., 2006, 128, 7438-7439. (h) Enders, D.; Dhulut, S.; Steinbusch, D.; Herrbach, A. Asymmetric total synthesis of (-)-pironetin employing the SAMP/RAMP hydrazone methodology. Chem. Eur. J., 2007, 13, 3942-3949. (i) Bressy, C.; Vors, J.-P.; Hillebrand, S.; Arseniyadis, S.; Cossy, J. Asymmetric total synthesis of the immunosuppressant (-)-pironetin. Angew. Chem. Int. Ed., 2008, 47, 10137-10140. (j) Crimmins, M. T.; Dechert, A.-M. R. Enantioselective total synthesis of (-)-pironetin: iterative aldol reactions of thiazolidinethiones. Org. Lett., 2009, 11, 1635-1638.

[16] (a) Vogt, A.; McPherson, P. A.; Shen, X.-Q.; Balachandran, R.; Zhu, G.-Y.; Raccor, B. S.; Nelson, S. G.; Tsang, M.; Day, B. W. High-content analysis of cancer-cell-specific apoptosis and inhibition of in vivo angiogenesis by synthetic (-)-pironetin and analogs. Chem. Biol. Drug Des., 2009, 74, 358-368. (b) Lin, J.; Yue, X.; Huang, P.; Cui, D.; Qing, F.-L. Synthesis of gemdifluoromethylenated analogs of pironetin. Synlett, 2010, 267-275.

[17] (a) Uckun, F. M.; Mao, C.; Jan, S.-T.; Huang, H.; Vassilev, A. O.; Sudbeck, E. A.; Navara, C. S.; Narla, R. K. SPIKET and COBRA compounds as novel tubulin modulators with potent anticancer activity. Curr. Opin. Invest. Drugs, 2000, 1, 252-256. (b) Uckun, F. M.; Sudbeck, E. A.; Mao, C.; Ghosh, S.; Liu, X. P.; Vassilev, A.O.; Navara, C. S.; Narla, R. K. Structure-based design of novel anticancer agents. Curr. Cancer Drug Targ., 2001, 1, 59-71.

[18] (a) Uckun, F. M.; Mao, C.; Vassilev, A. O.; Navara, C.S.; Narla, R. K.; Jan, S.-T. A rationally designed anticancer drug targeting a unique binding cavity of tubulin. Bioorg. Med. Chem. Lett., 2000, 10, 1015-1018. Compound COBRA-0 is named WHI-261 in this paper. (b) Jan, S.-T.; Mao, C.; Vassilev, A. O.; Navara, C. S.; Uckun, F. M. COBRA-1, a rationally-designed epoxy-THF containing compound with potent tubulin depolymerizing activity as a novel anticancer agent. Bioorg. Med. Chem. Lett., 2000, 10, 11931197.

[19] (a) Uckun, F. M.; Mao, C.; Jan, S.-T.; Huang, H.; Vassilev, A. O.; Navara, C. S.; Narla, R. K. Spongistatins as tubulin targeting agents. Curr. Pharm. Des., 2001, 7, 1291-1296. (c) Uckun, F. M. Rationally designed anti-mitotic agents with pro-apoptotic activity. Curr. Pharm. Des., 2001, 7, 1627-1639.

[20] (a) Gerber-Lemaire, S.; Vogel, P. Spongistatins: biological activity and synthetic studies. Compt. Rend. Chimie, 2008, 11, 1382-1418. (b) Smith, A. B., III; Risatti, C.; Atasoylu, O.; Bennett, C. S.; Liu, J.; Cheng, H.; Ten Dyke, K.; Xu, Q. Design, synthesis, and biological evaluation of diminutive forms of $(+)$-spongistatin 1: lessons learned. J. Am. Chem. Soc., 2011, 133, 14042-14053.

[21] For reviews on natural products containing spiroacetal fragments and methods for the synthesis of such functional moieties, see: (a) Perron, F.; Albizati, K. F. Chemistry of spiroacetals. Chem. Rev., 1989, 89, 1617-1661. (b) Brimble, M. A.; Farès, F. A. Synthesis of bis-spiroacetal ring systems. Tetrahedron, 1999, 55, 7661-7706. (c) Aho, J. E.; Pihko, P. M.; Rissa, T. K. Nonanomeric spiroacetals in natural products: structures, sources, and synthetic strategies. Chem. Rev., 2005, 105, 4406-4440.

[22] Pettit, G. R.; Cichacz, Z. A.; Gao, F.; Herald, C. L.; Boyd, M. R.; Schmidt, J. M.; Hooper, J. N. A. Antineoplastic agents. 257. Isolation and structure of spongistatin-1. J. Org. Chem., 1993, 58, 13021304.

[23] Uckun, F. M.; Mao, C.; Vassilev, A.O.; Huang, H.; Jan, S.-T. Structure-based design of a novel synthetic spiroacetal pyran as a pharmacophore for the marine natural product spongistatin 1 . Bioorg. Med. Chem. Lett., 2000, 10, 541-545.

[24] Smith, A. B., III; Corbett, R. M.; Pettit, G. R.; Chapuis, J.-C.; Schmidt, J. M.; Hamel, E.; Jung, M. K. Synthesis and biological evaluation of a spongistatin AB-spiroacetal analog. Bioorg. Med. Chem. Lett., 2002, 12, 2039-2042.

[25] Marco, J. A.; García-Pla, J.; Carda, M.; Murga, J.; Falomir, E.; Trigili, C.; Notararigo, S.; Díaz, J. F.; Barasoain, I. Design and synthesis of pironetin analogs with simplified structure and study of their interactions with microtubules. Eur. J. Med. Chem., 2011, 46, 1630-1637.

[26] Jan, S.-T.; Li, K.; Vig, S.; Rudolph, A.; Uckun, F. M. Stereoselective synthesis of a versatile intermediate for the total synthesis of mono- and bis-THF containing annonaceous acetogenins. Tetrahedron Lett., 1999, 40, 193-196.

[27] (a) Lipshutz, B. H.; Sengupta, S. Organocopper reagents: substitutions, conjugate additions, carbo/metallocuprations and other reactions. Org. React., 1992, 41, 135-631. (b) Krause, N., Ed. Modern Organocopper Chemistry; Wiley-VCH: Weinheim, Germany, 2004.

[28] Zhang, J.; Li, Y.; Wang, W.; She, X.; Pan, X. Concise asymmetric total synthesis of obolactone. J. Org. Chem., 2006, 71, 2918-2921.

[29] Greene, T. W.; Wuts, P. G. M. Protective Groups in Organic Synthesis, $3^{\text {rd }}$ Ed.; John Wiley and Sons: New York, 1999; pp. 45-48.

[30] (a) Tsuji, J. In: Addition reactions with formation of carbon-oxygen bonds (iv): the Wacker oxidation and related reactions. Comprehensive Organic Synthesis; Trost, B. M.; Fleming, I.; Winterfeldt, E., Eds.; Pergamon Press, Oxford, 1993, vol. 7, pp. 449-468. (b) Takacs, J. M., Jiang, X.-T. The Wacker reaction and related alkene oxidation reactions. Curr. Org. Chem., 2003, 7, 369-396. (c) Cornell, C. N., Sigman, M. S. Recent progress in Wacker oxidations: moving toward molecular oxygen as the sole oxidant. Inorg. Chem., 2007, 46, 1903-1909.

[31] (a) Mancuso, A. J.; Swern, D. Activated dimethyl sulfoxide: useful reagents for synthesis. Synthesis, 1981, 165-185. (b) Tidwell, T. T. Oxidations of alcohols to carbonyl compounds with alkoxysulfonium ylides: the Moffatt, Swern, and related oxidations. Org. React., 1990, 39, 297-572.

[32] Cowden, C. J.; Paterson, I. Asymmetric aldol reactions using boron enolates. Org. React., 1997, 51, 1-200.

[33] The aldol addition of the enolborane of $\beta$-alkoxy methyl ketone 13 to aldehyde 16 took place with moderate 1,5-anti selectivity. This remote induction has previously been observed by Evans and coworkers in related cases: Evans, D. A.; Côté, B.; Coleman, P. J.; Connell, B. T. 1,5-Asymmetric induction in boron-mediated $\beta$ alkoxy methyl ketone aldol addition reactions. J. Am. Chem. Soc., 2003, 125, 10893-10898. In contrast, the aldol addition of the enolborane of $\beta$-alkoxy methyl ketone 13 to aldehyde ent-16 took place with moderate 1,5-syn selectivity (see Supplementary Material).

[34] For a review on this type of aldol reactions, see: Dias, L. C.; Aguilar, A. M. 1,5-Asymmetric induction in boron-mediated aldol reactions of $\beta$-oxygenated methyl ketones. Chem. Soc. Rev., 2008, 37, 451-469.

[35] Oosawa, F.; Asakura, S. Thermodynamics of the Polymerization of Proteins. Academic Press, London, 1975.

[36] For a NMR study of the solution conformation of spongistatin 1, aided by computational calculations, see: Atasoylu, O.; Furst, G.; Risatti, C.; Smith, A. B., III. The solution structure of (+)spongistatin 1 in DMSO. Org. Lett., 2010, 12, 1788-1791.

[37] For a recent synthesis of the spiroacetal fragments of spongistatin 1, see: Flowers, C. L.; Vogel, P. Short diastereoselective synthesis of the C1-C13 (AB spiroacetal) and C17-C28 fragments (CD spiroacetal) of spongistatin 1 and 2 through double chain-elongation reactions. Chem. Eur. J., 2010, 16, 14074-14082.

[38] Buey, R. M.; Calvo, E.; Barasoain, I.; Pineda, O.; Edler, M. C.; Matesanz, R.; Cerezo, G.; Vanderwal, C. D.; Day, B. W.; Sorensen, E. J.; López, J. A.; Andreu, J. M.; Hamel, E.; Díaz, J. F. Cyclostreptin binds covalently to microtubule pores and lumenal taxoid binding sites. Nature Chem Biol., 2007, 3, 117-125.

[39] Yang, C.; Barasoain, I.; Li, X.; Matesanz, R.; Liu, R.; Sharom, F. J.; Yin, D. L.; Díaz, J. F.; Fang, W. S. Overcoming tumor drug resistance mediated by P-glycoprotein overexpression with high affinity taxanes: A SAR study of C-2 modified 7-acyl-10deacetylcephalomannines. ChemMedChem., 2007, 2, 691-701.

[40] De Ines, C.; Leynadier, D.; Barasoain, I.; Peyrot, V.; Garcia, P.; Briand, C.; Rener, G. A.; Temple, C. Jr. Inhibition of microtubules and cell-cycle arrest by a new 1-deaza-7,8-dihydropteridine antitu- 
mor drug, CI-980, and by its chiral isomer, NSC-613863. Cancer Res., 1994, 54, 75-84.

[41] Buey, R. M.; Barasoain, I.; Jackson, E.; Meyer, A.; Giannakakou, P.; Paterson, I.; Mooberry, S.; Andreu, J. M.; Díaz, J. F. Microtu- bule interactions with chemically diverse stabilizing agents: Thermodynamics of binding to the paclitaxel site predicts cytotoxicity. Chem. Biol., 2005, 12, 1269-1279.
Received: ???????????

Revised: ???????????? 